Józef M. DOŁĘGA*

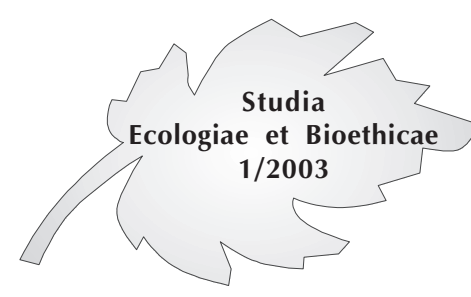

\title{
W kierunku dziedziny i dyscypliny nauk ekologicznych (środowiskowych)
}

\section{Wprowadzenie}

Istnieje w Polsce kilka klasyfikacji nauk, a mianowicie: Polskiej Akademii Nauk, Komitetu Badań Naukowych, Centralnej Komisji ds. Tytułu Naukowego i Stopni Naukowych oraz funkcjonuje szczegółowa klasyfikacja nauk przyjęta przez Fundację Nauki Europejskiej i Unię Europejską. $\mathrm{W}$ artykule tym przedstawimy klasyfikację nauk występującą $\mathrm{w}$ Polsce, w Fundacji Nauki Europejskiej i w Unii Europejskiej oraz zaprezentujemy rejestr nauk ekologicznych faktycznie występujących w praktyce uniwersyteckiej i wskażemy na potrzebę utworzenia dziedziny nauk ekologicznych (środowiskowych) oraz dyscypliny nauk ekologicznych (środowiskowych).

\section{Polskie klasyfikacje nauki}

1. Dziedziny i dyscypliny wyróżniane w klasyfikacji nauki przyjmowanej przez Komitet Badań Naukowych (informacja z dnia 7 października $2003 \mathrm{w}$ internacie). Oto ten zapis:

1. Nauki Humanistyczne

1.1. Filozofia

1.2. Teologia

1.3. Nauki o Literaturze, Bibliotekoznawstwo i Informacja Naukowa

1.4. Językoznawstwo

1.5. Nauki o Sztuce

1.6. Psychologia i Pedagogika

1.7. Nauki Historyczne

1.8. Archeologia i Etnologia

Instytut Ekologii i Bioetyki Uniwersytet Kardynała Stefana Wyszyńskiego w Warszawie. 
2. Nauki Społeczne, Ekonomiczne i Prawne

2.1. Prawo

2.2. Ekonometria i Statystyka

2.3. Ekonomia

2.4. Organizacja i Zarządzanie

2.5. Socjologia i Nauki Polityczne

2.6. Polityka Społeczna i Demografia

3. Nauki Matematyczne, Fizyczne i Astronomia

3.1. Matematyka

3.2. Fizyka

3.3. Badania Kosmiczne

3.4. Astronomia

4. Nauki Biologiczne, Nauki o Ziemi i Ochrona Środowiska

4.1. Biologia Molekularna, Biochemia i Biofizyka

4.2. Biotechnologia

4.3. Biologia

4.4. Geologia i Geofizyka

4.5. Geografia i Oceanologia

4.6. Ekologia

4.7. Ochrona Środowiska Przyrodniczego

5. Nauki Medyczne

5.1. Biologia Medyczna

5.2. Nauki Kliniczne Niezabiegowe

5.3. Nauki Kliniczne Zabiegowe

5.4. Zdrowie Publiczne i Kultura Fizyczna

5.5. Medycyna Wieku Rozwojowego

5.6. Nauki Farmaceutyczne

6. Nauki Rolnicze i Leśne

6.1. Biologiczne Podstawy Produkcji Roślinnej

6.2. Agrotechnika

6.3. Nauki Ogrodnicze

6.4. Biologiczne Podstawy Produkcji Roślinnej

6.5. Zootechnika

6.6. Inżynieria Rolnicza

6.7. Technologia Żywności i Żywienia Człowieka

6.8. Kształtowanie Obszarów Rolnych i Leśnych oraz Gospodarka Wodna i Leśna

6.9. Ekonomika i Organizacja Rolnictwa oraz Społeczna Transformacja Wsi 
6.10. Weterynaria

6.11. Rybactwo i Owady Użytkowe

6.12. Leśnictwo i Drzewnictwo

7. Mechanika, Budownictwo i Architektura

7.1. Mechanika

7.2. Eksploatacja, Wibroakustyka i Diagnostyka Maszyn i Systemów

7.3. Budowa Maszyn

7.4. Technologia i Automatyzacja Maszyn i Produkcji

7.5. Budownictwo i Materiały Budowlane

7.6. Architektura i Urbanistyka

7.7. Inżynieria Środowiska

8. Inżynieria Materiałowa i Technologie Materiałowe

8.1. Nauki o Materiałach

8.2. Metalurgia, Odlewnictwo i Przetwórstwo Metali

8.3. Inżynieria Powierzchni i Łączenia Materiałów

8.4. Technologie Materiałowe - Ceramika, Szkło, Spieki, Materiały Złożone

8.5. Technologie Materiałowe - Polimery Naturalne i Sztuczne, Włókiennictwo

9. Chemia, Technologia Chemiczna oraz Inżynieria Procesowa i Ochrona Środowiska

9.1. Nauki Chemiczne

9.2. Chemia Techniczna

9.3. Inżynieria Chemiczna i Procesowa

10. Elektrotechnika, Energetyka i Metrologia

10.1. Elektrotechnika

10.2. Energetyka

10.3. Miernictwo Interdyscyplinarne

11. Elektronika, Automatyka i Robotyka, Informatyka i Telekomunikacja

11.1. Automatyka i Robotyka

11.2. Elektronika

11.3. Informatyka

11.4. Telekomunikacja

11.5. Technika w Medycynie

11.6. Metody Komputerowe w Nauce 
12. Górnictwo, Geodezja i Transport

12.1. Górnictwo

12.2. Geologia Inżynierska, Hydrogeologia i Geofizyka Górnicza

12.3. Systemy i Środki Transportu

12.4. Spalinowe Zespoły Napędowe

12.5. Geodezja i Miernictwo Górnicze

2. Wykaz dziedzin nauki i sztuki oraz dyscyplin naukowych i artystycznych, w zakresie których mogą być nadawane stopnie naukowe według Centralnej Komisji do Spraw Tytułu Naukowego i Stopni Naukowych (System Informacji Prawnej Lex, 5/2003).

1. Nauki biologiczne

1.1. biochemia

1.2. biofizyka

1.3. biologia

1.4. biotechnologia

1.5. ekologia

2. Nauki chemiczne

2.1. biochemia

2.2. chemia

2.3. technologia chemiczna

3. Nauki ekonomiczne

3.1. ekonomia

3.2. nauki o zarządzaniu

3.3. towaroznawstwo

4. Nauki farmaceutyczne

5. Nauki fizyczne

5.1. astronomia

5.2. biofizyka

5.3. fizyka

5.4. geofizyka

6. Nauki humanistyczne

6.1. archeologia

6.2. bibliologia

6.3. etnologia

6.4. filozofia

6.5. historia

6.6. językoznawstwo 
6.7. literaturoznawstwo

6.8. nauki o polityce

6.9. nauki o poznaniu i komunikacji

6.10. nauki o sztuce

6.11. nauki o zarządzaniu

6.12. pedagogika

6.13. psychologia

6.14. religioznawstwo

6.15. socjologia

7. Nauki leśne

7.1.drzewnictwo

7.2. leśnictwo

8. Nauki matematyczne

8.1.informatyka

8.2. matematyka

9. Nauki medyczne

9.1. biologia medyczna

9.2. medycyna

9.3. stomatologia

10. Nauki o kulturze fizycznej

11. Nauki o Ziemi

11.1. geofizyka

11.2. geografia

11.3. geologia

11.4. oceanologia

12. Nauki prawne

12.1. nauka o administracji

12.2. prawo

12.3. prawo kanoniczne

13. Nauki rolnicze

13.1. agronomia

13.2. inżynieria rolnicza

13.3. kształtowanie środowiska

13.4. ogrodnictwo

13.5. rybactwo

13.6. technologia żywności i żywienia

13.7. zootechnika 
14. Nauki techniczne

14.1. architektura i urbanistyka

14.2. automatyka i robotyka

14.3. biocybernetytka i inżynieria biomedyczna

14.4. budowa i eksploatacja maszyn

14.5. budownictwo

14.6. elektronika

14.7. elektrotechnika

14.8. geodezja i kartografia

14.9. górnictwo

14.10. informatyka

14.11. inżynieria chemiczna

14.12 inżynieria materiałowa

14.13. inżynieria środowiska

14.14. mechanika

14.15. metalurgia

14.16. technologia chemiczna

14.17. telekomunikacja

14.18. transport

14.19. włókiennictwo

15. Nauki teologiczne

16. Nauki weterynaryjne

17. Nauki wojskowe

18. Sztuki filmowe

19. Sztuki muzyczne

20. Sztuki plastyczne

21. Sztuki teatralne

3. Kierunki studiów, które mają określone standardy przez Ministerstwo Edukacji Narodowej i Sportu

1. archeologia

2. architektura krajobrazu

3. astronomia

4. automatyka i robotyka

5. bibliotekoznawstwo i informacja naukowo-techniczna

6. biologia

7. biotechnologia

8. budownictwo

9. chemia

10. dziennikarstwo i komunikacja społeczna

11. edukacja artystyczna w zakresie sztuki muzycznej

12. edukacja artystyczna w zakresie sztuk plastycznych

13. ekonomia 
14. elektronika i telekomunikacja

15. elektrotechnika

16. etnologia

17. filologia

18. filologia polska

19. finanse i bankowość

20. fizyka

21. fizyka techniczna

22. geodezja i kartografia

23. geografia

24. geologia

25. gospodarka przestrzenna

26. górnictwo i geologia

27. historia

28. historia sztuki

29. informatyka i ekonometria

30. inżynieria chemiczna i procesowa

31. inżynieria materiałowa

32. inżynieria środowiska

33. kulturoznawstwo

34. leśnictwo

35. matematyka

36. mechanika i budowa maszyn

37. metalurgia

38. muzykologia

39. nawigacja

40. oceanografia

41. oceanotechnika

42. ochrona dóbr kultury

43. ochrona środowiska

44. ogrodnictwo

45. papiernictwo i poligrafia

46. pedagogika

47. pedagogika specjalna

48. pielęgniarstwo

49. politologa

50. prawo kanoniczne

51. psychologia

52. rolnictwo

53. rybactwo

54. socjologia

55. stosunki międzynarodowe

56. technika rolnicza i leśna 
57. technologia chemiczna

58. technologia drewna

59. technologia żywności i żywienia człowieka

60. teologia

61. towaroznawstwo

62. turystyka i rekreacja

63. weterynaria

64. włókiennictwo

65. wychowanie fizyczne

66. wychowanie techniczne

67. zarządzanie i inżynieria produkcji

68. zarządzanie i marketing

69. zootechnika

\section{Europejskie klasyfikacje nauki}

Z europejskich klasyfikacji nauki przytaczamy szczegółową klasyfikację nauk przyjętą przez Fundację Nauki Europejskiej i Unię Europejską.

Matematyka i informatyka

1. Statystyka i prawdopodobieństwo

2. Algebra i teoria liczb

3. Geometria i topologia

4. Analiza i cząstkowe równania różniczkowe

5. Matematyka stosowana

6. Podstawy matematyki

7. Logika i semantyka

8. Algorytmy

9. Sygnały, przetwarzanie mowy i obrazu, grafika komputerowa i współdziałanie człowiek - komputer

10. Technika programowania

11. Bazy danych i systemy informatyczne

12. Inżynieria wiedzy i sztuczna inteligencja

13. Systemy adaptacyjne i robotyka

14. Równoległe i rozproszone obliczenia, architektura komputerowa

15. Inne działy matematyki i informatyki

\section{Fizyka}

1. Pola i cząstki elementarne

2. Fizyka jądrowa

3. Fizyka jądrowa i cząsteczkowa

4. Optyka

5. Płyny i plazma 
6. Fizyka statystyczna

7. Astronomia, astrofizyka i kosmologia

8. Materia skondensowana - własności mechaniczne i termiczne

9. Materia skondensowana - własności elektroniczne, magnetyczne i nadprzewodnictwo

10. Materia skondensowana - materiały miękkie i fizyka polimerów

11. Fizyka zjawisk powierzchniowych

12. Biofizyka

13. Oprzyrządowanie i fizyka stosowana

14. Inne działy fizyki

\section{Chemia}

1. Synteza, nowe cząsteczki i metody

2. Mechanizmy i kinetyka reakcji

3. Chemia biologiczna, medyczna i farmaceutyczna

4. Techniki instrumentalne, analiza i sensory

5. Chemia komputerowa i modelowanie

6. Chemia zjawisk powierzchniowych, koloidy i kataliza heterogeniczna

7. Aspekty molekularne nowych materiałów

8. Chemia techniczna

9. Inne działy chemii

\section{Nauki biologiczne}

1. Biofizyka molekularna

2. Biologia molekularna i biochemia

3. Genom i genetyka

4. Mikrobiologia (wirusologia $\mathrm{z}$ uwzględnieniem AIDS)

5. Biologia komórki

6. Biologia rozwoju

7. Immunologia i nowotwory

8. Farmakologia i toksykologia

9. Fizjologia

10. Patologia (z uwzględnieniem nauk klinicznych i weterynaryjnych)

11. Neurofizjologa ( $\mathrm{z}$ uwzględnieniem psychologii)

12. Nauki o roślinach

13. Rolnictwo i leśnictwo

14. Rybołówstwo i akwakultura (kultura wodna)

15. Nauki środowiskowe (z uwzględnieniem ekologii, nauki o ewolucji, ochrony przyrody i zróżnicowania biologicznego)

16. Biotechnologia

17. Biologia i nauki społeczne ( $\mathrm{z}$ uwzględnieniem epidemiologii)

18. Inne działy nauk biologicznych 
Nauki o Ziemi

1. Klimatologia

2. Obserwacje Ziemi, zdalne monitorowanie

3. Środowiskowe nauki o Ziemi

4. Geografia

5. Geologia

6. Geofizyka

7. Geotechnika

8. Meteorologia, badanie atmosfery

9. Oceanografia

10. Badania złóż rud i ropy naftowej

11. Gleboznawstwo

12. Wulkanologia

13. Inne działy nauki o Ziemi

\section{Nauki inżynierskie}

1. Inżynieria mechaniczna

2. Inżynieria transportu

3. Inżynieria lądowa i wodna

4. Elektrotechnika

5. Elektronika

6. Telekomunikacja

7. Automatyka, sprzęt komputerowy, robotyka

8. Inżynieria chemiczna

9. Inżynieria środowiska

10. Inżynieria materiałowa

11. Inżynieria jądrowa

12. Inne działy nauk inżynieryjnych

Ekonomia, nauki społeczne i humanistyczne

1. Nauki polityczne, prawo

2. Nauki humanistyczne ( $\mathrm{z}$ uwzględnieniem psychologii)

3. Socjologia

4. Makroekonomika

5. Nauki finansowe

6. Gospodarka międzynarodowa

7. Metody badawcze, modelowanie

8. Zarządzanie przedsiębiorstwem

9. Środki komunikacji masowej

10. Ekonomika sektorowa

11. Otoczenie i środowisko geograficzne

12. Polityka transportu

13. Ekonomiczne aspekty technologii i innowacyjności 
14. Ekonomia społeczna

15. Mikroekonomia

16. Inne działy ekonomii, nauk społecznych i humanistycznych

\section{Rejestr nauk ekologicznych (środowiskowych)}

1. Ekologia - termin i definicję tej nauki po raz pierwszy podał Ernest Haeckel w 1866 roku. Rozumienie ekologii w ujęciu E. Haeckla (1834-1919) i uściślone przez S. A. Forbesa (1844-1930) w 1895 roku przetrwało do naszych czasów jak podaje Kazimierz A. Dobrowolski ${ }^{1}$. Ekologia jako nauka biologiczna badająca organizmy flory i fauny w środowiskach biotycznych i abiotycznych jest podstawą kształtującej się w drugiej połowie XX wieku ekologii człowieka i ekologii społecznej ${ }^{2}$.

2. Ekologia człowieka koncentruje się na badaniu wpływu czynników środowiska społecznego i przyrodniczego na organizm ludzki oraz nad możliwościami jego adaptacji do tego środowiska. Ustala się pogląd, że ekologia człowieka staje się dyscypliną o bardzo szerokim przedmiocie badań (np. por. N. Wolański).

3. Ekologia społeczna bada zjawiska z pogranicza socjologii, geografii, demografii i ekologii i ekologii człowieka. W ostatnim dziesięcioleciu XX wieku powstaje pilna potrzeba wyodrębnienia dodatkowej dyscypliny naukowej lub rozwiniętego działu w ekologii człowieka, a mianowicie - ekologii rodziny ludzkiej.

4. Ekologia rodziny ludzkiej - problematyka ta została podjęta na konferencji międzynarodowej zorganizowanej przez Instytut Filozofii, Centrum Ekologii Człowieka i Bioetyki, Instytut Studiów nad Rodziną w Augustowie w dniach 30-31 maja 2000 roku. Na konferencji tej wypracowano główne pojęcia z zakresu ekologii rodziny ludzkiej oraz wskazano na problemy i zagadnienia dotyczące rodziny ludzkiej. Całość dorobku z tej konferencji opublikowano w trzech tomach serii Episteme $(7,8,9) .^{3}$

1 Por. K. A. Dobrowolski, Polskie nauki ekologiczne wobec wyzwań globalnych i zadań praktycznych $w$ kraju, w: Ziemia domem człowieka, pod red. J. L. KRAKOWIAKA, BD, Warszawa 1997, 5-14.

2 Por. T. Umiński, Ekologia - środowisko - przyroda, WsiP, Warszawa 1996, 12-16; H. WIŚNIEWSKI i G. KowalewsKI, Ekologia z ochrona i ksztattowaniem środowiska, AGMEN, Warszawa 1997, 14-18; A. Horst, Ekologia człowieka, Warszawa 1976; B. CAMPBELL, Ekologia człowieka. Historia naszego miejsca w przyrodzie od prehistorii do czasów wspótczesnych, tłum. M. A. BITNER, WN PWN, Warszawa 1995; D. KIEŁCZEWsKI, Ekologia społeczna, UwB, Białystok 1998; K. ŁastowsKi, Ekologia a filozofia. Od ekologii biologicznej do ekologii jako wiedzy humanistycznej, w: Wprowadzenie do filozoficznych problemów ekologii, pod red. A. PApuzińskiego, WSP, Bydgoszcz 1999, 11-54.

3 Episteme 7(2000): Ekologia rodziny ludzkiej, pod red. J. W. Czrtoszewski, J. M. DolęGA, AUM, Olecko 2000; Episteme 8(2000): Rodzina w nauce i kulturze, pod red. J. W. CZRTO- 
5. Sozologia - termin ten pochodzi od greckiego słowa "sodzo", które oznacza "ochraniać”, „ratować”, „pomagać”. Został on wprowadzony do polskiego słownika naukowego przez Walerego Goetela ${ }^{4}$ na początku lat sześćdziesiątych $X X$ wieku. Według niego termin ten oznacza naukę o ochronie przyrody, o ochronie naturalnego środowiska człowieka. Znaczenie tego terminu zostało wzbogacone nowymi treściami i tym samym poszerzono jego zakres. Wyrazem tego jest bogata literatura przedmiotowa, a terminu tego używa się - coraz częściej na określenie nauki o ochronie środowiska społeczno-przyrodniczego.

$\mathrm{W}$ badaniach naukowych z zakresu sozologii podejmuje się następujące problemy i zagadnienia:

- opis faktyczny stanu przyrody w Polsce i świecie;

- określenie obiektów, które zanieczyszczają i niszczą środowisko;

- przeprowadzenie badań technicznych i technologicznych w celu wprowadzania urządzeń oczyszczających i technologii nieuciążliwych dla środowiska;

- badanie wpływu zmienionego środowiska na organizmy żywe i na człowieka;

- tworzenie zabezpieczeń prawnych i administracyjnych w skali krajowej i międzynarodowej $\mathrm{w}$ celu realizacji programów ochrony środowiska;

- budzenie świadomości moralnej i etycznej, wrażliwej na jakość środowiska przyrodniczego i społecznego;

- szukanie środków zmniejszających zanieczyszczenie środowiska i eliminowanie źródeł jego zanieczyszczeń;

- badanie wpływu środowiska na stan psychiczny człowieka;

- prowadzenie medycznych badań nowych jednostek chorobowych, powstałych pod wpływem zmienionego środowiska;

- zabezpieczenie tak zwanych "czystych" rezerw genetycznych;

- wychowanie - na różnych szczeblach edukacji narodowej - w duchu wrażliwości na wartość środowiska człowieka.

SZEwski, J. M. DoŁĘGA, AUM, Olecko 2000; Episteme 9(2000): Edukacja ekologiczna w rodzinie, pod red. J. W. CzRToszewski, J. M. DolęGA, AUM, Olecko 2000.

4 W. Goetel, Sozologia - nauka o ochronie przyrody i jej zasobów, Kosmos A 15(1966)473482, przedruk, tamże, 21(1972) z. 1, 31-38; Edukacja ekologiczna wobec wspótczesności $i$ wyzwań przyszłości, Przyroda i Człowiek (Zeszyt specjalny) Opole - Pokrzywna 1995; Człowiek wobec świata, pod red. Z. Hulla i W. TulibackIEGo, PTF i AR-T, Olsztyn 996; Ekofilozofia i bioetyka, pod red. W. TYвURSKIEgo, TOP Kurier, Toruń 1996; Ekonomia - ekologia -etyka, pod red. W. Tyburskiego, TOP Kurier, Toruń 1996.21(1972)31-38; por. J. M. DoleGA, Z zagadnien sozologii, w: Z zagadnien filozofii przyrodoznawstwa i filozofii przyrody, pod red. K. KŁósaKa, t. 4, ATK, Warszawa 1982, 328-327; K. R. Mazurski, Podstawy sozologii, SUDETY, Wrocław 1998; J. JARON, Ekologia, sozologia, ekofilozofia, ekoetyka, ekonomia, proekologiczna. Przegląd zagadnień, HEIODOR, Warszawa 1997. 
Aspekt zakresowy nazwy "sozologia” obejmuje problemy i zagadnienia dotyczące środowiska przyrodniczego i społecznego, w którym żyje człowiek. A zatem dotyczy to przyrody nieożywionej i ożywionej oraz antroposfery. Wszystkie te obszary rozpatrywane są $\mathrm{w}$ aspekcie ochrony naturalnych właściwości poszczególnych obiektów przyrodniczych i ich wpływu na życie i zdrowie człowieka. W aspekcie tym, który jest charakterystyczny dla sozologii, mieszczą się badania naturalnych właściwości obiektów przyrody nieożywionej i ożywionej oraz ich właściwości powstałe pod wpływem działalności człowieka. Badania te dotyczą również nowo powstałych właściwości środowiska i ich wpływu na zdrowie i życie człowieka, a także ich wpływu na kondycję biologiczną innych gatunków żyjących na ziemi.

6. Sozotechnika ${ }^{5}$ - termin ten oznacza całość badań naukowo-technicznych i technologicznych związanych $\mathrm{z}$ ochroną środowiska oraz z wprowadzaniem do produkcji nowych technologii nie niszczących środowiska lub przynajmniej nieuciążliwych dla tego środowiska.

7. Sozoekonomia ${ }^{6}$ - (czasem nosi nazwę ekoekonomia) dział ekonomii zajmujący się kosztami produkcji wraz z nakładami na ochronę środowiska, mieści się to $\mathrm{w}$ tak zwanym rachunku sozoekonomicznym przedsiębiorstwa, lub jednostki administracyjnej państwa.

8. Etyka środowiskowa ${ }^{7}$ - (inne nazwy, to: etyka ekologiczna, ekoetyka) wyrażenie to w środowiskach naukowych w Polsce zaczyna się utrwalać na oznaczenie nauki zajmującej się zasadami i normami postępowania człowieka wobec środowiska przyrodniczego (biotycznego i abiotycznego) i społecznego. Wyróżnia się w niej kilka orientacji, a mianowicie:

5 Por.: J. Bańka, Zarys filozofii techniki, UŚ, Katowice 1981; A. KIEPAS, Moralne wyzwania nauki i techniki, Warszgraf, Katowice - Warszawa 1992; J. SzYmański, Technika a eksperymentalne sprawdzanie praw nauki, WAW, Poznań 1994; Człowiek - technika - środowisko. Człowiek wspótczesny wobec wyzwań końca wieku, red. naukowy, A. KIEPAs, UŚ, Katowice 1999; Inżynieria procesowa, WPW, Warszawa 2000.

6 Problemy sozologiczne aglomeracji miejsko-przemystowych. Wybrane zagadnienia, pod red. Z. MateCKIEgo, KIŚPAN, Biuletyn (1993) nr 1; Problemy sozologiczne aglomeracji miejsko-przemystowych. Huta im. Tadeusza Sendzimira, pod red. Z. MAŁEcKIEGo, KIŚPAN, Biuletyn (1994) nr 1; J. T. WIMPENNY, Wartość środowiska. Metody wyceny ekonomicznej, tłum. K. Kafel, I. SzymaniaK, PWE, Warszawa 1995; Podejmowanie inwestycji proekologicznych i źródta ich finansowania, pod red. B. PoskroBKI, PB, Białystok 1995; Ekonomia - ekologia - etyka, pod red. W. TyBURSKIEGo, IF UMK, Toruń 1996; Ekonomiczna wycena środowiska przyrodniczego, pod red. G. Andersona i J. ŚLESZYŃsKIEGo, WeiŚŚ, Białystok 1996.

7 Por.: W. TyвURSKI, Etyka i ekologia, PKE, Toruń 1995; Z. PIĄTEK, Etyka środowiskowa, Nowe spojrzenie na miejsce człowieka w przyrodzie, IF UJ, Kraków 1998; Etyka środowiskowa. Teoretyczne i praktyczne implikacje, pod red. W. TYBURSKI, IF UMK i PKE, Toruń 1998; A. Pawłowski, Odpowiedzialność za przyrodę, WPL, Lublin 1999; J. ŁuкомsкI, Próba zbudowania chrześcijańskiej etyki środowiska naturalnego, Radom 1998; W. TyвURsкI, Główne kierunki i zasady etyki środowiskowej, w: Wprowadzenie do filozoficznych problemów ekologii, dz. cyt., 97-132. 
- holistyczną odmianę etyki środowiskowej,

- biocentrycznie zorientowaną etykę środowiskową,

- etykę ochrony zwierząt,

- antropocentryczną odmianę etyki środowiskowej.

Etyka środowiskowa jest w ciągłym rozwoju i pojawiają się coraz to nowe orientacje związane $\mathrm{z}$ kierunkami filozoficznymi lub religiami albo z określonym światopoglądem.

9. Bioetyka ${ }^{8}$ - jest określona przez Tadeusza Ślipko jako „dział filozoficznej etyki szczegółowej, która ma ustalić oceny i normy (reguły) moralne ważne w dziedzinie działań (aktów ludzkich) polegających na ingerencji w granicznych sytuacjach związanych z zapoczątkowaniem życia, jego trwaniem i śmiercią". Problematykę bioetyczną w Instytucie Ekologii i Bioetyki UKSW kontynuuje i rozwija Wojciech Bołoz. Natomiast w Akademii Podlaskiej szerokie badania historyczne i bieżące prowadzi Józef Jaroń rejestrując dorobek naukowy w zakresie bioetyki w Polsce i na świecie.

10. Prawodawstwo ekologiczne ${ }^{9}$ - pod tym wyrażeniem rozumie się procesy tworzenia prawa ochrony środowiska, jego wdrażania i egzekwowania. Prawo ochrony środowiska jest podstawą dla wielu zarządzeń praktycznych na szczeblu lokalnym, regionalnym, krajowym, kontynentalnym i globalnym - wykonanie tych zarządzeń uwarunkowane jest środkami finansowymi.

11. Ekofilozofia - jako nowa nauka filozoficzna, ma już bogaty system koncepcji. W tym miejscu nie dokonujemy szczegółowej analizy poszczególnych koncepcji ekofilozofii, a tylko prezentujemy ich rejestr i krótką charakterystykę.

1) Ekofilozofia jako filozofia ekologii ${ }^{10}$ - wyrażenie "filozofia ekologii" $\mathrm{w}$ podstawowym znaczeniu funkcjonuje $\mathrm{w}$ filozofii nauki i oznacza

8 Por. T. ŚLIPKo, Granice życia. Dylematy wspołczesnej bioetyki, ATK, Warszawa 1988; W. BoŁOZ, Życie w ludzkich rękach - podstawowe zagadnienia bioetyczne, ATK i ADAM, Warszawa 1997.

9 Por.: R. Paczuski, Prawo ochrony środowiska. Stan prawny na dzień 30 czerwca 1994, OWBranta, Bydgoszcz 1994; L. ŁUKASzuK, Międzynarodowe prawo morza, WN Scholar, Warszawa 1997; D. KIEŁCZEwsKI, Mechanizmy rozwoju prawa ochrony środowiska, UwB, Białystok 1998; Prawa człowieka w państwie ekologicznym, pod red. R. SoBAŃsKI, WATK, Warszawa 1998; Ekologia i prawo, pod red. A. PrzYBorowskiej-KLIMCZAK, TNKUL, Lublin 1999; J. Stochlak, Polskie prawo ochrony środowiska, WN GB, Warszawa 2002.

10 Z. Hull, Filozofia ekologii jako nowa dziedzina filozofowania, w: Filozofia i bioetyka. Materiay VI Polskiego Zjazdu Filozoficznego w Toruniu 5-9 wrzesnia 1995 r., Sekcja Bioetyki $i$ Ekofilozofii, pod red. W. Tyburskiego, TOP Kurier, Toruń 1996, 9-29; por. A. PAPuziński, Metafizyczne dziedzictwo nauki jako problem filozofii ekologii, w: Ekofilozofia i bioetyka, 2942; Problemy filozofii ekologii, w: Wprowadzenie do filozoficznych problemów ekologii, pod red. A. Papuzinskiego, WSP, Bydgoszcz 1999, 55-96; J. M. DoŁĘGA, Z filozofii nauk ekologicznych, w: Ochrona środowiska spoteczno-przyrodniczego w filozofii i teologii, pod red. J. M. DoŁęGi, J. W. Czartoszewskiego, A. Skowrońskiego, WUKSW, Warszawa 2001, 25-37. 
teorię i metodologię ekologii. $\mathrm{W}$ ostatnich dziesiątkach lat $\mathrm{XX}$ wieku wyrażenie to zawiera $\mathrm{w}$ swojej treści i zakresie wiele elementów z szeroko rozumianych zagadnień filozoficznych i ochrony środowiska. Przykładem takich ujęć są prace Zbigniewa Hulla.

2) Ekofilozofia jako ekologia człowieka ${ }^{11}$ - wyrażenie „ekologia człowieka" zastosowane przez Napoleona Wolańskiego do określenia syntezy wyników badań naukowych z zakresu antropologii przyrodniczej, ekologii i nauk medycznych. W ujęciu tym jest duży zakres zagadnień i refleksji antropologicznych o charakterze filozoficznym.

3) Ekofilozofia jako ekologia humanistyczna ${ }^{12}$ - w zapowiedzi Stanisława Zięby - ma prowadzić badania naukowe nad życiem człowieka w jego aspekcie specyficznie ludzkim i osobowym.

4) Ekofilozofia jako ekologia głęboka ${ }^{13}$ - koncepcja ta zawiera zagadnienia filozoficzne nie tylko $\mathrm{w}$ założeniach, ale również $\mathrm{w}$ rozwiązaniach problemów szczegółowych związanych z kryzysem i katastrofami ekologicznymi oraz z kryzysem moralnym człowieka.

5) Ekofilozofia jako filozofia ekologiczna ${ }^{14}$ - wyrażenie wprowadzone przez Henryka Skolimowskiego, w zestawieniu z takim wyrażeniem, jak „filozofia logiczna”, które już funkcjonuje w słowniku naukowym, może z biegiem czasu uprawomocnić się w języku filozoficznym.

11 N. Wolański, Glossary of terms for human ecology, Warsaw 1990; Czynniki rozwoju człowieka. Wstęp do ekologii człowieka, pod red. N. WolansKI, PWN, Warszawa 1972; A. Horst, Ekologia człowieka, PWN, Warszawa 1976; Ekologia człowieka. Historia wspótczesności, pod red. B. KuźNICKA, IHN PAN, Warszawa 1995; N. Wolański, Nowoczesność jako sprawność w przystosowaniu czlowieka do środowiska, „Prakseologia” (1992) Nr 1-2, 105-127.

12 Por. S. Zį̨вA, Ku ekologii humanistycznej, „Człowiek i Przyroda” (1994) Nr 1, 7-13; Humanizm ekologiczny, vol. 1: Jakiej filozofii potrzebuje ekologia, ochrona przyrody a ochrona człowieka, pod red. L. PAwŁowskiego i S. ZiĘBY, WU PL, Lublin 1992; W. TYBUrski, Pojednać się z Ziemią. W kręgu zagadnień humanizmu ekologicznego, IPIR, Toruń 1993; Humanizm ekologiczny, vol. 4B: Technika szansq czy zagrozeniem (aspekty techniczne), pod red. Iwo Pollo i Z. M. KozaKa, WU PL, Lublin 1996; S. Zį̨BA, Natura i człowiek w ekologii humanistycznej, ZECKUL, Lublin 1998.

13 B. Devall, G. Sessions: Ekologia głęboka. Żyć w przekonaniu, iż Natura coś znaczy, tłum. E. Margielewicz, Pusty Obłok, Warszawa 1994; R. BzDAK, Problem możliwości teoretycznego uzasadniania głębokiej ekologii, w: Człowiek $i$ środowisko..., 91-96; A. SYNowIECKI, Człowiek - z ziemi wzięty, „Człowiek i Przyroda” (1994) Nr 1, 41-92; K. WALoszczYK, Kryzys ekologiczny w świetle ekofilozofii, WPL, Łódź 1996, 228-241.

14 Por.: H. Sкоlıмowski, Filozofia żyjąca.Ekofilozofia jako drzewo życia, Pusty Oblok, Warszawa 1992; D. KIEeCZEWSKI, Wybrane nurty filozofii ekologicznej, WFUW, Białystok 1993, 5 32; K. WaLoszczyк, Kryzys ekologiczny w świetle ekofilozofii, WPL, Łódź 1996, 207-228; H. Sкоlimowsкi, Medytacje, Astrum, Wrocław 1991; H. SкоLıмоwsкi, Wizje Nowego Millenium, Kraków 1999; H. Skolimowski, J. K. GóRecki, Zielone oko kosmosu. Wokót ekofilozofii w rozmowie i esejach, Atla 2, Wrocław2003. 
6) Ekofilozofia jako ekozofia $\mathrm{T}^{15}$ - jest budowana na filozofii związanej z kierunkami panteistycznymi - zarówno historycznymi, jak i współczesnymi oraz o założenia ekologii głębokiej.

7) Ekofilozofia jako filozofia kryzysu ekologicznego ${ }^{16}$ - orientacja ta dotyczy przede wszystkim zagadnień etycznych, prawnych, politycznych i ekonomicznych związanych z kryzysem ekologicznym oraz ekologii jako nowego paradygmatu polityki.

8) Ekofilozofia jako ujęcie systemowo-informacyjne ekorozwoju ${ }^{17}$ - ujęcie to zawarte $\mathrm{w}$ pracach Lesława Michnowskiego znajduje uzasadnienie $w$ prognozach rozwoju człowieka i o założenia zrównoważonego ekorozwoju.

9) Ekofilozofia jako ekologia uniwersalistyczna ${ }^{18}$ - pojawia się w kontekście ujęć filozofii uniwersalistycznej, a inaczej mówiąc uniwersalizmu, jako metafilozofii, prezentowanej w Polsce między innymi w pracach Janusza Kuczyńskiego.

10) Ekofilozofia jako praktyczna filozofia przyrody ${ }^{19}$ - ujęcie to akcentuje zagadnienia przede wszystkim praktyczne i bioetyczne związane $\mathrm{z}$ kryzysem ekologicznym. Koncepcja ta prezentowana jest w literaturze przedmiotowej w Polsce jest prezentowana między innymi przez Zbigniewa Łapko i Annę Lemańską.

11) Ekofilozofia jako część filozofii przyrody ${ }^{20}$ - koncepcja ta jest związana $\mathrm{z}$ ujęciem filozofii przyrody orientacji arystotelesowsko-tomistycznej, gdzie już wyróżnia się filozofię przyrody nieożywioną (kosmofilozofię) i filozofię przyrody ożywionej (biofilozofię) oraz filozofię środowiska społeczno-przyrodniczego (ekofilozofię).

15 Por. B. Devall, G. Sessions, Ekologia głęboka, 289-293; M. Ryszkiewicz, Matka Ziemia w przyjaznym kosmosie. Gaja i zasada antropiczna w dziejach myśli przyrodniczej, WN PWN, Warszawa 1994.

16 Por. Ed Phillips, Crisi in Atmosphere: The greenhause factor, D. B. Clark and Co. Phoenix 1990; V. Hosle, Philosophie der okologischen Krise, C. H. Beck, Munchen 1994; Z. Piątek, Filozoficzne korzenie kryzysu środowiskowego, w: Człowiek $i$ środowisko..., 43-50.

17 L. Michnowski, Jak żyć? Ekorozwój albo..., WEiS, Białystok [brw]; Ekorozwój szansa przetrwania cywilizacji. Materialy z konferencji PKE, pod red. B. Zaufal, M. BialeckieJ, t. 3, WAG-H, Kraków 1986; L. Michnowski, Czy regres człowieczeństwa? LTN, Warszawa 1999.

18 Por. J. KucZYŃski, Udomowienie Ziemi. Interpretacja Leszka Kotakowskiego projektu metanoi, w: Ziemia naszym domem, pod red. J. KuczYNSKIEGO, CU UW, Warszawa 1996, 155 178; por. J. KuCZYŃski, Wstęp do uniwersalizmu, t. 1: Ogrodnicy świata, BD, Warszawa 1998; t. 2: Młodość Europy i wieczność Polski, BD, Warszawa 1999.

19 Por. Z. Łeтко, Ku ekofilozofii, „Studia Philosophiae Chistianae” 30(1994) Nr 1, 21-34; tenże, Ekofilozofia jako praktyczna filozofia przyrody, w: Cztowiek i środowisko..., 37-42; A. LEMAŃSKA, Praktyczna filozofia przyrody alternatywa klasycznej filozofii przyrody, „Studia Philosophiae Chistianae" 33(1997) Nr 1, 133-138; Z. ŁEPKO, Antropologia kryzysu ekologicznego, WUKSW, 2003.

20 Por. J. M. DoŁĘGA, W kierunku ekofilozofii, w: Ekofilozofia i bioetyka, 19-25. 
12) Ekofilozofia jako kulturalistyczna filozofia ekologii reprezentowana w Polsce przez Andrzeja Papuzińskiego ${ }^{21}$.

13) Ekofilozofia jako enwironmentalizm ${ }^{22}$ - proponowana przez Wiesława Sztumskiego z Instytutu Filozofii Uniwersytetu Śląskiego w Katowicach.

14) Ekofilozofia jako samodzielna nauka filozoficzna ${ }^{23}$ - o wyraźnie określonym statucie epistemologicznym i metodologicznym.

$\mathrm{W}$ powstających naukach podstawowym zagadnienie jest wypracowanie statusu epistemologicznego i metodologicznego oraz struktury zagadnień merytorycznych stanowiących pewną zwartą logiczną całość. W tym miejscu pomijamy szczegółowe analizy zagadnień metateoretycznych, a jedynie zwróci się uwagę Czytelnika na przedmiot badań ekofilozofii.

Każda nauka ma swoją prehistorię. Podobnie i ekofilozofia ma już swoją prehistorię, a mianowicie wszyscy uczeni zajmujący się zagrożeniami i ochroną środowiska społeczno-przyrodniczego, a zwłaszcza autorzy przytoczonych powyżej koncepcji tej nauki, są prekursorami ekofilozofii. Biorąc pod uwagę aktualny stan badań naukowych z zakresu ekofilozofii, nie sposób dzisiaj określić definitywnie przedmiotu badań tej nauki. Jednak na podstawie istniejącej literatury i toczących się dyskusji na różnych sympozjach i konferencjach naukowych, można przyjąć robocze określenia przedmiotu ekofilozofii: przedmiotem badań ekofilozofii jest istota i natura środowiska społeczno-przyrodniczego, jego właściwości ilościowe i jakościowe oraz dwustronne związki przyczynowe między antroposferą a środowiskiem.

W nurcie określonego myślenia filozoficznego poznanie z zakresu ekofilozofii zmierzałoby do poznania środowiska realnie i faktycznie istniejącego; do poznania w aspektach koniecznościowych i przyczynowych, a nie tylko przygodnych; do uzyskiwania uzasadnień tez ekofilozoficznych racjami logicznymi, ontycznymi, realnymi i przyczynowymi ${ }^{24}$. Inaczej mówiąc: ekofilozofia jest nauką o systemowym ujęciu problematyki filozoficznej środowiska społeczno-przyrodniczego.

21 Por.: A. PAPUZIŃSKI, Życie - nauka - ekologia. Prolegomena do kulturalistycznej filozofii ekologii, WSP, Bydgoszcz 1998.

22 Por.: W. Sztumski, Enwironmentalizm i cywilizacja życia, UŚ, Katowice 1997.

23 Por. J. M. DoŁĘGA, Z zagadnien metateoretycznych i merytorycznych ekofilozofii, Studia Philosophiae Christianae 32(1996) Nr 1, 270-278; J. M. DoŁĘGA, Ekologia w teologii i filozofii chrzescijanskiej, w: Wprowadzenie do filozoficznych problemów ekologii, pod red. A. PAPUzIŃskiego, WSP, Bydgoszcz 1999,133-163; J. M. DoŁĘGA, Problematyka ochrony środowiska społeczno-przyrodniczego $w$ sozologii i ekofilozofii, w: Ochrona środowiska w filozofii i teologii, pod red. J. M. DoŁęGa i J. W. CzRToszewski, WATK, Warszawa 1999, 10-26.

24 Por. K. KŁósaK, Z teorii i metodologii filozofii przyrody, KSW, Poznań 1980, 46-49, 105, 113; J. M. DoŁĘGA, Stosunek ruchu do materii w ujęciu klasycznej filozofii przyrody, ATK, Warszawa 1986, 29-30. 
Zasadniczym źródłem informacji o środowisku są różne nauki szczegółowe, a szczególnie ekologia i sozologia. Wydobycie problematyki filozoficznej z naukowego obrazu środowiska społeczno-przyrodniczego i kulturowego należy między innymi do zadań ekofilozofii.

Z zagadnień metateoretycznych ekofilozofii wymieniamy tylko te, które stanowią zasadniczą strukturę przedmiotową tej nauki. Do niej należy problematyka ogólnofilozoficzna, antropologiczna, aksjologiczna i edukacyjna dotycząca środowiska społeczno-przyrodniczego łącznie ze środowiskiem kulturowym.

Ogólnofilozoficzna problematyka ekofilozofiii ${ }^{25}$ dotyczy istoty i natury środowiska społeczno-przyrodniczego, jego właściwości ilościowych i jakościowych, zmian zachodzących w tych właściwościach oraz związków przyczynowych między antroposferą a biosferą. Chodzi tutaj przede wszystkim o zdanie sprawy $\mathrm{z}$ aktualnego stanu środowiska, źródeł zmian zachodzących $\mathrm{w}$ tym środowisku, jego wpływu na życie i zdrowie człowieka, jak również szukanie podstaw filozoficznych ochrony tego środowiska. Podstawą do prowadzenia badań w tym zakresie są dane z przyrodniczych nauk szczegółowych i antropologicznych. Podejmowana problematyka ogólnofilozoficzna w ekofilozofii i próby jej rozwiązania są oparte $\mathrm{w}$ sensie metodologicznym o tak zwany naukowy obraz świata, $\mathrm{w}$ tym przypadku chodzi przede wszystkim o naukowy obraz środowiska społeczno-przyrodniczego.

Antropologiczna problematyka ekofilozofiii ${ }^{26}$ dotyczy przede wszystkim zagadnień filozoficznych związanych z demografią, ontogenezą, antropopresją, migracją oraz z strukturalnymi elementami antroposfery, do których zalicza się przede wszystkim naukę, technikę i technologię, sztukę i religię. Punktem wyjścia do tego rodzaju badań są dane z antropologii przyrodniczej, filozoficznej, społecznej i kulturowej oraz z ekologii człowieka, sozotechniki, religiologii, filozofii i historii nauki, historii i filozofii kultury. Podejmowana filozoficzna problematyka antropologiczna $\mathrm{w}$ ekofilozofii oraz sposoby jej rozwiązywania zależy od przyjmowanych przez autorów systemów filozoficznych.

Aksjologiczna problematyka ekofilozofii ${ }^{27}$ występuje przy wartościowaniu życia, zdrowia człowieka, środowiska. Podstawy wartościo-

25 Por. S. ZiЕ̨BA, Życie w aspekcie ekologicznym, „Człowiek i przyroda” (1995) Nr 2, 5-21; J. DęвowsKi, Filozoficzne źródta refleksji ekofilozoficznych, WSP, Olsztyn 1996.

26 Por. N. Wolański, Rozwój biologiczny człowieka, cz. 1 i 2, wyd. 6, PWN, Warszawa 1986; S. KowalczyK, Zarys filozofii człowieka, WD, Sandomierz 1990; Człowiek - osoba - płeć, pod red. M. Wóıcik, IsnR ATK, Warszawa 1998.

27 Por. K. KŁoskowski, O naczelnej zasadzie etycznej relacji w: Cztowiek - środowisko, w: Człowiek $i$ środowisko..., 107-112; W. TYBURSKI, Etyka środowiskowa a paradygmat antropocentryzmu, w: Ekofilozofia i bioetyka, 65-72; Z. РіĄTEK, Dylematy etyki środowiskowej, w: Ekofilozofia i bioetyka, 43-64. Ponadto por. 16 artykułów w pracy zbiorowej na temat: Ekonomia, ekologia, etyka, pod red. W. Tyburski, IFUMK, Toruń 1996; J. Łukomski, Próba zbudowania chrześcijańskiej etyki środowiska naturalnego, WDR, Radom 1998. 
wania wypracowywane są $\mathrm{w}$ aksjologii lub filozofii bytu. $\mathrm{W}$ ramach naszej koncepcji ekofilozofii życie oraz życie i zdrowie człowieka ujmujemy jako wartości najwyższe, ale nie absolutne. Natomiast środowisko społeczno-przyrodnicze traktuje się jako wartość podstawową i dobro wspólne. Podstawą takich analiz w tym przypadku jest aksjologia lub filozofia bytu, które są podstawą wypracowania etyki ogólnej oraz etyki środowiskowej, a nawet prawodawstwa ekologicznego. Wydaje się, że wiedza naukowa związana ze środowiskiem społeczno-przyrodniczym oraz wypracowana i akceptowana etyka środowiskowa mogą stać się podstawą dla ekorozwoju.

Edukacyjna problematyka ekofilozofii ${ }^{28}$ dotyczy przede wszystkim podstaw filozoficznych wychowania proekologicznego, a ściślej mówiąc wychowania sozologicznego $\mathrm{w}$ rodzinie, $\mathrm{w}$ szkole, $\mathrm{w}$ masmediach, $\mathrm{w}$ organizacjach społecznych, religiach oraz $\mathrm{w}$ ogólnej edukacji narodowej. Kształtowanie świadomości wrażliwej na wartość środowiska społecznoprzyrodniczego zależy również od programów nauczania w przedszkolach, szkołach podstawowych, średnich i na uczelniach wyższych oraz od powszechnej edukacji ekologicznej dorosłych. Ponadto jest to zadanie dla wszystkich zdających sprawę z jakości aktualnego środowiska i jego wpływu na życie na naszej planecie oraz z jego wpływu na życie i zdrowie człowieka w naszej Ojczyźnie, jak i na całym świecie. Jest to zadanie nie tylko dla filozofów - jak pisze M. Barnier ${ }^{29}$ - ale dla wszystkich mających wpływ na świadomość społeczną w Polsce i w świecie.

12. Ekoteologia ${ }^{30}$ - postulowana nauka teologiczna zbierająca w całość już opracowane szczegółowe zagadnienia ekologiczne związane $\mathrm{z}$ teologią, a mianowicie: grzech ekologiczny, ekologiczny rachunek sumienia, zagadnienie zbawienia świata, moralność ekologiczna, rozwój duchowy człowieka i inne - nauka ta świadczy o dużym zainteresowaniu teologów zagadnieniami ekologicznymi.

28 Por. Materialy II Ogólnopolskiej Konferencji Ochrona środowiska w nauczaniu i wychowaniu, pod red. M. R. Dudzińskiej i L. PawŁowskiego,WU PL, Lublin 1993; Chronić by przetrwać, pod red. C. NAPIÓRKowsKiego i W. Koca, WOF, Niepokalanów 1992; Edukacja ekologiczna wobec wspótczesności i wyzwań przyszłości, Przyroda i Człowiek Zeszyt Specjalny, Opole - Pokrzywna 1995; Edukacja środowiskowa. Agenda 21 - realizacja zadań edukacyjnych, pod red. D. Cichy, IBE, Warszawa 1997; Problemy dydaktyki i wychowania w Akademii Rolniczej w Poznaniu, 14: Edukacja i świadomość ekologiczna, ARP, Poznań 1997; I. FudALI, Ekologiczne wyzwania regionalnych programów edukacji środowiskowej, PKE, Kielce 1997; J. FratcZaK, Świadomość ekologiczna dzieci, młodzieży i dorostych $w$ aspekcie edukacji szkolnej i nieszkolnej, WSP, Bydgoszcz 1995; J. M. DoŁĘGA, Znaczenie sozologii $i$ ekofilozofii w systemie edukacji ekologicznej, w: Hipoteza ekologii ekologicznej, pod. red. J.L. Krakowiak, J. M. DoŁęGa, BD, Warszawa 1999, 53-65.

29 M. BARNiER, Atlas wielkich zagrożeń, tłum. M. Jarosiewicz, WN-T, Warszawa 1995, 9.

30 Por.: M. Ozonowski, W kierunku ekoteologii, w: Ochrona środowiska w filozofii i teologii, pod red. J. M. DoŁęGi i J. W. Czrtoszewskiego, ATK, Warszawa 1999, 252-256; S. Urbań- 
13. Polityka ekologiczna ${ }^{31}$ - wyrażenie to oznacza badania naukowe, które dotyczą większych przedziałów czasowych i terytorialnych. W badaniach tych należałoby uwzględnić czas przynajmniej kilku pokoleń, a terytorium, region, kontynent lub całą planetę Ziemię z jej najbliższym otoczeniem kosmicznym. Badania nad świadomością ekologiczną społeczeństwa oraz wdrażanie prawa ekologicznego staje się przedmiotem badań i zainteresowań wielu polityków - naukowców.

14. Psychologia ekologiczna - nowy dział psychologii zajmujący się wpływem środowiska przyrodniczego i społecznego, a w tym miejskiego i wiejskiego na psychikę człowieka (badania Adama Bieli z KUL-u i Andrzeja Eliasza z WSPS i PAN-u)

15. Ekomedycyna ${ }^{32}$ - nowy dział medycyny zajmujący się wpływem zmieniającego się środowiska na zdrowie człowieka, rozpoznanie nowych jednostek chorobowych i sposobami ich leczenia (Anna Latawiec UKSW).

16. Edukacja środowiskowa ${ }^{33}$ - jeszcze raz wracamy do objaśnień tego wyrażenia, które coraz powszechniej używane w szkolnictwie, oznacza to wszystko, co niesie w swojej treści wyrażenie: edukacja ekologiczna i edukacja sozologiczna oraz pewne aspekty terminu szeroko rozumianego środowiska. Dlatego edukacja środowiskowa zawiera w swojej treści następujące aspekty: biologiczny, abiotyczny, sozologiczny i społeczny. Zatem w tak rozumianej edukacji środowiskowej należy uwzględnić, zarówno $\mathrm{w}$ procesie nauczania jak i wychowania, podstawową informację dotyczącą systemów żywych prostych i złożonych, elementów abiotycznych środowiska, sposobów i środków ochrony wszystkich elementów środowiskowych oraz znaczenia środowiska społecznego dla ca-

SKI, Mistyka ekologii ducha ludzkiego, tamże, 203-221; J. BAJDA, Grzech ekologiczny, tamże, 222-242; J. W. CZRToszewski, Ekologiczne rachunki sumienia, tamże, 243-251; M. Ozorowski, Kościót a ekologia, tamże,281-283; A. Skowroński, „Kwestia ekologiczna” w nauczaniu Jana Pawła II, tamże, 284-281; Z. ŚwIERCZeK, Ekologia - Kościót i Św. Franciszek, WSDOO.F, Kraków 1990; J. GRZESICA, Ochrona środowiska naturalnego człowieka, KSJ, Katowice 1993; A. L. SzAFrański, Chrześcijańskie podstawy ekologii, ZEC KUL, Lublin 1993; P. KęDZIerski, Kościót i ekologia, WSD, Rzeszów 1997.

31 Por.: S. KozŁowski, W drodze do ekorozwoju, WN PWN, Warszawa 1997, 187-209; Zasady ekopolityki w rozwoju obszarów wiejskich, pod red. L. RYszKowski i S. BAŁAZY, ZBŚRiL PAN, Poznań 1995; H. Lisicka, Organizacje ekologiczne w polskich systemach politycznych, Wrocław 1997; Świadomość ekologiczna i spoteczne ruchy „Zielonych” w Polsce, pod red. W. Mirowskiego i przy współpracy P. Glísskiego, IFiS PAN, Warszawa 1999.

32 Por. J. Wróbel, Człowiek i medycyna, WKS, Kraków 1999; S. Kornas, Wspótczesne eksperymenty medyczne w ocenie etyki katolickiej, CWD, Częstochowa 1986.

33 Por. A. Kalinowska, Ekologia wybór na nowe stulecie, Warszawa 2002; Mówić o ochronie przyrody, red.: M. GrzegorczyK, J. Perzanowska, Z. J. KiJAs, Z. Mirek, IOP PAN..., Kraków 2002; Rola wyższych uczelni w edukacji dla ekorozwoju, pod red. T. Borysa, WEiŚ, Białystok 2003. 
łego procesu edukacji środowiskowej. W edukacji ekologicznej bardzo ważną rolę mają tak zwane nauki ekologiczne, które dostarczają nam podstawowej informacji naukowej z wielu ważnych obszarów wchodzących $\mathrm{w}$ istotną strukturę środowiska. Czy nauki te można nazywać dziedziną nauk ekologicznych? Prawdopodobnie z czasem należy udzielić uzasadnionej pozytywnej odpowiedzi. Dzisiaj mamy cały szereg nauk ekologicznych, o których informacje powyżej zamieszczono, a one wszystkie wspierają edukację środowiskową.

17. Kultura ekologiczna. Żeby zaistniała „kultura ekologiczna” w danym społeczeństwie, $\mathrm{w}$ pełnym tego wyrażenia znaczeniu, to musi dokonać się wiele zmian $\mathrm{w}$ zasadniczych elementach kultury, a mianowicie: $\mathrm{w}$ nauce, technice i technologii, sztuce i religii. Zastanówmy się na zmianami jakie zaszły i zachodzą $w$ tych wymienionych elementach kultury ${ }^{34}$.

Nauka. Wymienione nauki, które już mają określony status metodologiczny i epistemologiczny potwierdzają procesy zachodzące $\mathrm{w}$ poznaniu naukowym na początku XXI wieku. Koncentrują się one wokół następujących zagadnień:

- epistemologicznych związanych z teorią poznania naukowego, a dotyczące określenia przedmiotu badań danej nauki, wypracowania definicji i odpowiedniej koncepcji tej nauki oraz szukanie podstaw historycznych tego kierunku badań naukowych;

- metodologicznych, w których podejmuje się analizę dominujących form rozumowania, wypracowanie metod badawczych i całej metodologii badań naukowych w tej dziedzinie nauk;

- merytorycznych, które koncertują się od ochrony środowiska, przez świadomość ekologiczną aż do zagadnień etycznych, prawnych, moralnych i teologicznych;

- praktycznych, w których chodzi głównie o zastosowania praktyczne konkretnych rozwiązań i to zarówno w naukach technicznych i technologicznych jak i w humanistycznych.

Technika i technologia. Zmiany jakie obserwujemy w tej dziedzinie dotyczą powstawania nowych technik ochrony środowiska i wypracowywania nowych technologii nieszkodliwych dla środowiska lub przynajmniej nieuciążliwych dla niego.

34 Por:: Hipoteza ekologii holistycznej, pod red. J. L. Krakowiaka i J. M. DolęGa, CUUW i PFŻ, BD, Warszawa 1999; Ekologia ducha, pod red. J. L. Krakowiaka, CUUW, PFŻ, BD, Warszawa 1999; H. Sкоlıмowski, Święte siedlisko człowieka, CUUW, PFŻ, BD, Warszawa 1999; A. PAPUZIŃski, Świadomość ekologiczna a kultura, w: Wprowadzenie do filozoficznych problemów ekologii, dz.cyt., 156-218; J. KUCZYŃsKI, Ogrodnicy świata. Wstęp do uniwersalizmu, t. 1, CU UW i WSEiZ, Warszawa1998; Podstawy kultury ekologicznej, pod red. J.M. DoŁĘGA, ZN KCiŚ przy P PAN, Warszawa 2002; Kultury tradycyjne a kultura globalna, pod red. J. Nikitoroeicz, M. Sobecki, D. Misiejuk, TH, Białystok 2001; J. M. DoŁĘGa, Religia istotnym elementem kultury, w: Chrześcijaństwo w kontekście judaizmu i islamu, pod red. M. Skierkowskiego, OW-P Adam, Warszawa 2003, 27-36. 
Sztuka. W tym filarze kultury obserwujemy działalność twórczą człowieka w różnych działach sztuki, a mianowicie: w poezji, literaturze, malarstwie, piosenkarstwie, rzeźbiarstwie, muzyce, fotografice. U wielu autorów pojawia się problematyka związana z zagrożeniami i katastrofami ekologicznymi.

Religia. We wszystkich kulturach świata religia stanowi istotny element strukturalny. Występuje ona i przenika inne elementy kultury jako system wartości sprzyjający rozwojowi człowieka. W tej warstwie kultury obserwujemy również wiele zmian zachodzących pod wpływem zjawisk zachodzących w środowisku społeczno-przyrodniczym, które prowadzą do zagrożeń i katastrof ekologicznych.

Czy zbiór tych zjawisk zachodzących w ramach kultury jest już kulturą ekologiczną społeczeństwa? Prawdopodobnie jeszcze nie, ale w dużym stopniu od tych zmian zależy powstanie i jakość kultury ekologicznej. Dlatego, na przykład: edukacja ekologiczna w znaczeniu właściwie wychowania i wykształcenia człowieka wrażliwego na środowisko społeczno-przyrodnicze powinna funkcjonować skutecznie $w$ ramach tak zwanej kultury ekologicznej, która ma dominującą rolę w procesach ochrony środowiska.

\section{Postulowana dziedzina: nauki ekologiczne (środowiskowe)}

W przytoczonych klasyfikacjach nauk ochrona środowiska jest wymieniona w Komitecie Badań Naukowych w punkcie 4 i 9 w następującym sformułowaniu: 4. Nauki biologiczne, nauki o Ziemi i Ochrona środowiska; 9. Chemia, technologia chemiczna oraz inżynieria procesowa i ochrona środowiska. Natomiast nie jest uwzględniona ochrona środowiska w dziedzinach wyróżnionych przez Centralną Komisję do Spraw Tytułu Naukowego i Stopni Naukowych.

$Z$ racji na ważność problematyki środowiskowej, badań naukowych prowadzonych przez wiele uniwersytetów i placówek naukowych pod różnymi nazwami należałoby wyróżnić nową dziedzinę pod nazwą: nauki o środowisku lub nauki środowiskowe.

\section{Postulowana dyscyplina: nauki ekologiczne (środowiskowe)}

Spis dyscyplin naukowych podany przez Komitet Badań Naukowych podaje następujące sformułowania na określenie dyscyplin związanych z środowiskiem: Ochrona środowiska przyrodniczego; Inżynieria środowiska. Natomiast w klasyfikacji Centralnej Komisji do Spraw Tytułu Naukowego i Stopni Naukowych znajdujemy następujące sformułowania: 
kształtowanie środowiska, inżynieria środowiska. W klasyfikacji nauk przyjmowanych przez Fundację Nauki Europejskiej i Unię Europejską wyróżnia się nauki środowiskowe $\mathrm{z}$ uwzględnieniem ekologii, nauki o ewolucji, ochrony środowiska i zróżnicowania biologicznego oraz inżynierię środowiska.

W związku z tym należałoby te dyscypliny faktycznie już istniejące włączyć do dziedziny nauk środowiskowych oraz inne o zaawansowanym statusie epistemologicznym i metodologicznym.

\section{Zakończenie}

Przedstawiona $\mathrm{w}$ tym artykule problematyka ukazuje potrzebę uwzględnienia $w$ polskich klasyfikacjach nauk dziedziny nauk ekologicznych lub $\mathrm{w}$ innym sformułowaniu dziedziny nauk środowiskowych. Oba wyrażenia są wystarczająco uzasadnione, aby je przyjąć i uwzględnić w polskiej klasyfikacji nauk. Ponadto w tej klasyfikacji wyróżniono dyscyplinę: nauki ekologiczne lub nauki środowiskowe. Wprowadzenie takiej dziedziny nauk ekologicznych (środowiskowych) i dyscypliny nauk ekologicznych (środowiskowych) umożliwi uczelniom wyższym nadawanie stopni naukowych i tytułu naukowego $\mathbf{w}$ dziedzinie nauk ekologicznych (środowiskowych) i w zakresie określonych dyscyplin nauk ekologicznych (środowiskowych) oraz $w$ kierunku studiów: ochrona środowiska. Wykształceni specjaliści w tym kierunku studiów, w tak określonej dyscyplinie i dziedzinie nauk ekologicznych (środowiskowych) mieliby formalną podstawę do prowadzenia badań naukowych o charakterze interdyscyplinarnym i systemowym oraz do tworzenia jednostek organizacyjnych $\mathrm{z}$ uprawnieniami do nadawania stopni naukowych $\mathrm{w}$ dyscyplinie nauk ekologicznych (środowiskowych) i tytułu naukowego w dziedzinie nauk ekologicznych (środowiskowych).

\section{W kierunku dziedziny i dyscypliny nauk ekologicznych (środowiskowych)}

Streszczenie

Przedstawiona $w$ tym artykule treść wskazuje na potrzebę uwzględnienia $\mathrm{w}$ polskich klasyfikacjach nauk dziedziny nauk ekologicznych lub w innym sformułowaniu dziedziny nauk środowiskowych. Oba wy- 
rażenia są wystarczająco uzasadnione, aby je przyjąć i uwzględnić w polskiej klasyfikacji nauk. Ponadto w tej klasyfikacji wyróżniono dyscyplinę: nauki ekologiczne lub nauki środowiskowe. Wprowadzenie takiej dziedziny nauk ekologicznych (środowiskowych) i dyscypliny nauk ekologicznych (środowiskowych) umożliwi uczelniom wyższym nadawanie stopni naukowych i tytułu naukowego $\mathbf{w}$ dziedzinie nauk ekologicznych (środowiskowych) i w zakresie określonych dyscyplin nauk ekologicznych (środowiskowych) oraz $\mathrm{w}$ kierunku studiów: ochrona środowiska. Wykształceni specjaliści w tym kierunku studiów, w tak określonej dyscyplinie i dziedzinie nauk ekologicznych (środowiskowych) mieliby formalną podstawę do prowadzenia badań naukowych o charakterze interdyscyplinarnym i systemowym oraz do tworzenia jednostek organizacyjnych $\mathrm{z}$ uprawnieniami do nadawania stopni naukowych $\mathrm{w}$ dyscyplinie nauk ekologicznych (środowiskowych) i tytułu naukowego w dziedzinie nauk ekologicznych (środowiskowych).

\title{
Towards the area and discipline of ecological (environmental) sciences
}

\author{
SUMMARY
}

The presented essence of this article reveals a need of taking an area of ecological sciences, or an area of environmental sciences - in other words, into account in the Polish classification of sciences. The both expressions are justified sufficiently to be accepted and taken into consideration in the Polish classification of sciences. Besides there was distinguished a discipline: ecological sciences, or environmental sciences. An application of such the area of ecological (environmental) sciences and the discipline of ecological (environmental) sciences will enable academical schools to confer scientifical degrees and scientifical title in the area of ecological (environmental) sciences and within the range of deternined disciplines of ecological (environmental) sciences, and a specialization: a preservation of environment. Educated specialists of this matter, of such the determined discipline and area of ecological (environmental) sciences, may have a formal basis to make researches of interdisciplinary and of system character, and to create organizational units with a license to confer the scientifical degrees in the discipline of ecological (environmental) sciences, and the scientifical title in the area of ecological (environmental) sciences. 